\title{
水害危険性が地価に与える影響の変化時点推定 一地域の水害危険性認識変容の把握に向けて一 DETECTING A CHANGE-POINT OF FLOOD RISK INFLUENCE ON LAND PRICES
}

\author{
井上 亮 1 - 永吉真也 2 ・小森大輔 3 \\ Ryo INOUE, Masaya NAGAYOSHI and Daisuke KOMORI \\ 1正会員 博 (工) 東北大学准教授 大学院情報科学研究科 人間社会情報科学専攻 \\ （率980-8579 仙台市青葉区荒巻字青葉6-6-06） \\ 2非会員 東北大学 大学院情報科学研究科 人間社会情報科学専攻 \\ 3 正会員 博 (農) 東北大学准教授 大学院環境科学研究科 先端環境創成学専攻
}

\begin{abstract}
Local governments publicize flood risk information aiming to mitigate future damage and loss; however, the way in which residents recognize and understand them is unclear. Several researches by analyzing land prices have quantified residents' level of flood risk understanding, with an assumption that land prices are influenced by the perception of flood risk levels. Assuming that residents' perception of flood risk increases when flood occurs is natural; however, earlier studies have not yet succeeded to identify changes between flood risk indices and land prices by using the time series analysis.

This study utilized land transaction prices of Kanda river basin, and found that the prices dropped immediately after the Great East Japan Earthquake in the high inland flooding risk area.
\end{abstract}

Key Words: change point detection, transaction land prices, flood risk, hedonic approach

\section{1. はじめに}

近年，地球温暖化により猛烈な降雨現象が増加し，水 害の発生が増加傾向にあるとされる1)。防災施設整備な どの従来型の水害対策のみでは対策が難しいその被害の 軽減を目指し，行政は洪水ハザードマップなど水害危険 度情報を作成し，地域住民に対して広報している。この 情報は，短期的には避難時機・経路や避難先の検討，長 期的には居住地域や土地利用の見直しの検討など，防災 対策への活用が期待されているが，それぞれの地域で必 ずしも有効に活用されているとは言えない. 水害危険度 情報が地域住民に届き，そこに示された水害危険性が適 切に認識・理解されているかは明らかではない.

この地域住民・社会が有する水害危険性に対する認識 の強さを把握する方法の一つとして，不動産価格，中で も地価に着目した研究が行われている2-5). これらの研 究では，地域住民・社会が有する水害危険性に対する認 識が，不動産市場における取引物件評価を通して地価に 反映されているとの仮説の下，水害危険度指標が地価に 与える影響の大きさを分析している．地域間比較や時系 列比較などを通して水害危険度指標が地価に与える影響 に差異が確認された場合に，地域住民の水害危険性認識
に地域格差や時系列変化があるとの結果を導いている. しかし，地域により水害危険度指標以外の土地属性に 対する不動産市場の評価も異なるため，水害危険度指標 に対する地価の反応の地域的差異が，地域住民・社会の 水害危険性認識度の差異を表すと判断することは難しい また， 時系列分析 ${ }^{45)}$ では地価公示価格が用いられること が一般的だが，地価公示点の空間密度は低いため水害危 険性の高い地域に多くの地価公示点が得られない点，地 価公示は年1回の公表で頻度が少ない点，また地価公示 価格の作成過程で時間遅れが生じる点などから，地価一 の影響が変化した時点を抽出することが難しく, 分析結 果として得られた変化時点の意味解釈が困難となる.

そこで本研究は，地価公示よりも時間的・空間的に高 い密度で情報が得られ，不動産市場における水害危険性 に対する評価の変化を即座に反映する取引地価を用いて， 土地属性に対する不動産市場の評価に違いが小さいと考 えられる中小河川流域の狭い領域を対象に，水害危険度 指標が地価に与える影響が変化した時点を抽出する．抽 出された変化時点やその前後の水害危険度指標が地価に 与える影響の推定結果から，地域住民・社会の水害危険 性認識に変化をもたらした要因を分析し，地域の水害危 険性に対する認識度の把握に向けた考察を行う。 


\section{2. 既往の水害危険性と地価の関係分析}

\section{（1）ヘドニック・アプローチ}

水害危険性などの環境要因は市場価格が存在しない非 市場財であるため，地価への影響を直接測定することは できない．環境要因などの非市場財の便益測定方法の一 つにキャピタリゼーション仮説を背景としたへドニッ ク・アプローチが存在する帛. キャピタリゼーション仮 説とは，住民の同質性・地域の開放性が成り立つとき， 環境改善便益は地価に反映されるとの仮説である. キャ ピタリゼーション仮説の下では，水害危険性などの環境 要因は地価に反映される.

ヘドニック・アプローチでは, 財の価格は財の有する 複数の属性の合成で決定されると考える．例えば，財の 価格 $R$ が財の属性 $z_{1}, \cdots, z_{k}$ の線形式で表せる場合,

$$
R=\beta_{0}+\beta_{1} z_{1}+\cdots+\beta_{k} z_{k}+\varepsilon \quad \varepsilon \text { : 攪乱項 }
$$

属性 $z_{i}$ の1単位あたりの便益は $\beta_{i}$ の推定值となる.

環境要因の一つである水害危険度指標の影響を把握す るため, ヘドニック・アプローチを用いて水害危険性と 地価の関係を分析する研究が数多く行われている. 地価 は，水害危険性を含む多くの土地属性により価格が決定 されていると仮定され，水害危険度の指標となる説明変 数として「標高」「河川までの距離」「浸水履歴」「予想浸水 深」, その他の説明変数として「地積」「形状」など物件固 有の属性，「最寄り駅までの距離」「主要駅までの所要時 間」など交通条件，「用途地域」所属する行政区域」など 地域特性を表す項目が用いられる.

\section{（2）水害危険性と地価の関係の分析}

本節では，水害危険性と地価の関係を分析する既往研 究を紹介した上で, 本研究の位置づけを明らかにする.

既往研究の前提となる考え方は，水害危険性が地価に 与える影響の大ささは，水害危険性の大きさそのものに よるとする考え方と，地域住民の水害危険性に対する認 識の強さによるとする考え方の2つに分けられる.

前者は，「客観的基準により評価された水害危険性が 高い土地は，不動産市場で安く評価される」ことを前提 とする研究である7)-13). 水害危険性が地価に与える影響 を利用し，防災投資の便益評価に活用されている11-13).

後者は，「地域住民・社会が水害危険性に対して有す る認識の強さが地価に反映される」ことを前提とした研 究2)-5)である。希少現象である水害の危険性は，日常生 活で知覚することが難しいため，他の環境条件とは異な り十分に地域住民・社会に浸透していない可能性が高い これらの研究では，客観的な水害危険性評価が地価に必 ずしも織り込まれているとは限らないとの前提に立つ.

本研究は後者の考え方に則り，地価分析を通した地域 住民・社会が持つ水害危険性に対する認識強さの把握を 検討する，既往研究では，異なる水害危険性指標に対す
る地価の反応の違いや，地域間・時系列比較による地価 の反応の地域差・時代差を分析し，水害危険性に対する 地域住民・社会の認識を考察している.

劉(2010) 2) は，不動産募集価格と複数の水害危険性指標 との関係を分析し，立地選択時に住民が考慮に入れてい ると考えられる指標の特定を行った. ただし，水害危険 性指標は強い相関を有するため，ヘドニック・アプロー チで用いる地価関数の当てはまりの良さで，住民が考慮 する水害危険性指標を特定することには限界がある.

寺本ら $(2008)^{3)}$ は，東京都の中小河川流域と大阪府寝屋 川流域の地域間比較を通した分析を行った．住宅用途の 地価公示価格に対して「標高」「浸水深」を水害危険度指標 としたヘドニック・アプローチを行い，両地域の浸水深 に対する地価の反応の違いから, 水害危険性認識に地域 差があることを確認した．ただし，水害危険度指標以外 の土地属性に対する不動産市場の評価は地域によって異 なるため, 水害危険度指標に対する地価の反応の地域的 差異が，地域住民・社会の水害危険性認識度の差異を表 すと判断することは難しい.

市川ら $(2002)^{4)}$ は，同一地域の時系列比較による分析を 行った. 過去数回水害を経験している寝屋川流域を対象 に，1970年から1990年まで各年の地価公示を用いた時系 列比較を行った。水害危険度指標として「標高」「川まで の距離」「川との標高差」「浸水履歴」を説明変数に設定し た地価関数のパラメータを推定し，水害危険度指標が地 価に与える影響の大きさや，水害発生による地価変化の 分析した. その結果, 水害危険度指標が大きいと地価が 低いこと，また，年により有意な水害危険度指標が異な ることを確認したが，水害発生後の地価下落や地価上昇 率の低下など, 水害発生が地価に直接影響を与える様子 は確認できていない.

また，篠村 $(2010)^{5)}$ は，東京都区部のハザードマップ公 表地域と非公表地域，集中豪雨被害の浸水地域と未浸水 地域に関して地域間・時系列比較を通して，ハザード マップ公表や水害発生に起因する地価変化の捕捉を目指 したDID分析を行った. ハザードマップ公表が原因とみ られる変化は確認されず，また，2005年に発生した水害 についても，直後の2006年では統計的に有意な変化は生 じず，2007年以降に地価下落が生じたという結果が得ら れており，これが水害に起因する反応かは明確ではない， このように時系列の地価データを用いた分析を通して 地域住民・社会の水害危険性認識の変容を分析する研究 が行われているが，水害などの事象発生に伴う地価変化 を十分には捕捉できていない. この原因の一つは, 分析 に地価公示を用いた点にあると考えられる. 地価公示は, 不動産取引の目安となる価格の情報提供を目的の一つと し，地域を代表する標準的な土地属性を持つ標準地の, 売り急ぎなどの取引当事者の事情に左右されない正常な 価格を公表することとしている. 地域一帯が浸水被害を 受けていない場合は，浸水域内にある物件の取引は特殊 
事例と見なされて地価公示価格に反映されない可能性が ある. 加えて, 年一度のみの公示で, 価格算定過程では 必然的に市場の価格動向に比べて時間遅れが生じる上, 時間的な平滑化が行われる場合もあるため，地価公示を 用いて即時的な地価の変化を捉えることは難しい．また， 公示地点数も限られるため, 浸水域内に多くの公示地点 が含まれていない可能性もある. これらの理由から，地 価公示を基に，水害などの事象発生が浸水域周辺の地価 に与える影響の分析に用いることは難しいと考えられる。

一方，取引地価は，全取引の把握を目指し多くの情報 が収集されるため浸水域やその周辺の情報も有し, 取引 日毎に地価を記録するため時間解像度が高く, 取引時の 地価を加工せずに記録するため市場参加者の評価を反映 した值を示寸，そのため，取引価格に基づく分析は，地 価公示に基づく分析よりも，水害に起因する地価変化を 明瞭に抽出できる可能性を有する，ただし，取引価格は， 取引当事者の事情を反映するため, 取引物件の標準的な 価格は必ずしも示さないことや，地価公示よりも多様な 属性を有する物件の取引が含まれているため, 価格分布 幅が広く属性の影響を除去することが難しいという分析 上の短所を有することには注意が必要である.

本研究は, 時系列の取引地価を利用して, 水害危険度 が地価に与える影響の程度が変化した時点を推定し, 地 域の水害危険度認識に影響を与えた事象を考察する。

\section{3. 変化時点推定手法}

変化時点推定では, 変化時点の前後をダミー変数で区 別する式(2)のモデルで分析することが一般的である.

$$
y_{i t}=\mathbf{x}_{\mathbf{i t}}^{\prime} \boldsymbol{\beta}_{\mathbf{B}}+\mathbf{x}_{\mathbf{i t}}^{\prime} \mathbf{I}_{\mathbf{t}}(\theta) \boldsymbol{\beta}_{\mathbf{C}}+\varepsilon_{i t}
$$

ただし $i$ : 地点, $t:$ 時点 $(=1, \ldots, T), \theta$ : 変化時点

$y_{i t}$ : 地点 $i$, 時点 $t$ 被説明変数

$\mathbf{x}_{\mathbf{i t}}$ : 地点 $i$, 時点 $t の$ 説明変数ベクトル

$\mathbf{I}_{\mathbf{t}}(\theta)$ : 変化時点の前後を表すダミー変数行列

$\boldsymbol{\beta}_{\mathrm{B}}, \boldsymbol{\beta}_{\mathrm{C}}$ : パラメータ (変化前: $\boldsymbol{\beta}_{\mathrm{B}}$, 変化後: $\left.\boldsymbol{\beta}_{\mathrm{B}}+\boldsymbol{\beta}_{\mathrm{C}}\right)$

$\varepsilon_{i t}$ :攪乱項

変化時点推定法の1つであるChow検定は, $\theta$ の設定值 を変化させてOLS推定を繰り返し, 最も当てはまりの良 い $\theta$ を変化時点とし, その下でパラメータ $\boldsymbol{\beta}_{0}, \boldsymbol{\beta}_{1}$ を推 定する. しかし，この方法ではパラメータ推定量は変化 時点 $\theta$ の条件付き分布に従うため, パラメータにバイ アスを生じる上，変化時点 $\theta$ の有意性は検定できない，

Spirling (2007) ${ }^{14)}$ は, Markov Chain Monte Carlo 法 (MCMC)を用いた，パラメータのバイアスを抑える式(2) の推定法を提案した. この手法では, 変化時点 $\theta$ も他 のパラメータと同時に推定するため, パラメータ推定結 果にバイアスが生じない上， $\theta$ の有意性を検定できる. 本研究は, この分析手法を用いて変化時点推定を行う.

\section{4. ケーススタディ}

\section{（1）分析対象地域と期間}

対象地域は，神田川・善福寺川・妙正寺川・江古田川 から構成される神田川水系の流域の内, 中上流域の新宿 区の山手線外，渋谷・中野・杉並・練馬区，武蔵野・三 鷹市の用途地域の指定が住居系または準工業の区域とす る(図-1)。また，対象期間は2001年から2013年とする.

この対象地域・期間には，地域住民の水害危険性認識 に影響を与えたと予想される種々の事象が発生している.

神田川は，以前はほぼ毎年外水汇濫によって被害を生 じる都市型中小河川であった. 対象期間前半には, 流域 で浸水面積が1haを超える水害が9回発生している. 対象 期間内で最大の水害は，2005年9月4日に発生した集中豪 雨によってもたらされ, 125.9haが浸水した.

しかし, 昭和60年代から治水事業が進められ, 特に 2005年の神田川・環状七号線地下調整池の第二期事業の 完成により治水機能が大幅に向上し, 流域の洪水被害が 大幅に減少している. このため, 地域住民の水害危険性 に対する認識に変化が生じていることが期待される.

また, 東日本大震災の発生も地域住民の防㷋意識に影 響を与えた可能性がある．流域では水害は生じていない ものの，多くの住民にとって災害について意識する機会 となったと予想される.

\section{（2）使用データ}

地価データは，国土交通省が作成した不動産取引事例 と地価公示を使用する.

不動産取引事例は，国土交通省土地鑑定委員会が取得 した，取引当事者へのアンケート調査などに基づく情報 である. 取引物件の価格や住所・地番, 地積など属性が 記録されているが，属性の詳細は現在一般には公開され ていない. 本研究は更地の取引事例23,880件を使用し, これを以後, 取引地価と記す。

地価公示は，この不動産取引事例を基に，標準地の毎 年1月1日時点における正常な価格を算定した情報である. 分析に使用寸る土地属性のうち，「地積」「指定容積率」 「最寄り駅「「最寄り駅までの距離」は不動産取引事例や地 価公示に記録された值を用いる．また，交通利便性指標 として「最寄り駅から主要駅までの鉄道所要時間」を用い

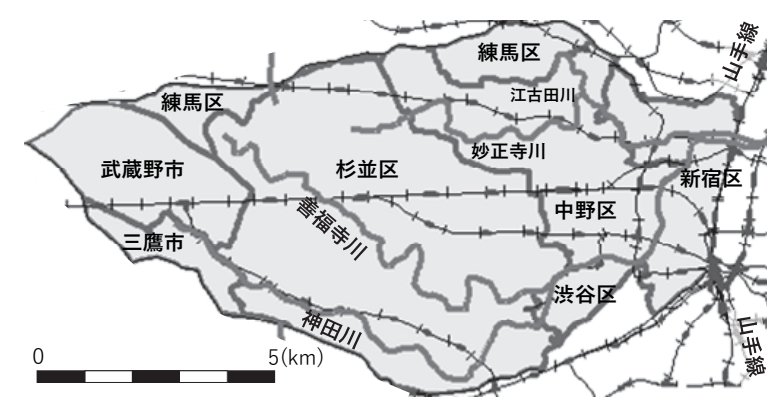

図-1 分析対象区域 
る. これは, 各物件の最寄り駅を平日朝 8 時に出発した 新宿・渋谷・池袋・東京駅までの2014年11月時点の時刻 表に基づく所要時間を，Yahoo!路線情報を用いて算出し, 国土交通省国土数值情報の2013年度駅別乗降客数を用い て加重平均して設定した.

ここで，2009年内の取引地価と2010年1月1日時点の地 価公示価格の記述統計量を表-1に示し, 両者の特徵を示 す. 取引地価の件数は地価公示の10倍以上存在し, 空間 的に高密度に分布している. 平均值・中央值はほぼ同水 準だが，取引地価は売り急ぎなど取引当事者の事情が含 まれているため, 分散が大きいことが確認できる.

水害危険度指標は，水害浸水履歴と地形に関する情報 を使用して作成する. 水害浸水履歴は, 分析対象期間に おける国土交通省水害区域図の内水・外水汇濫浸水域よ り抽出し, 地形は, 国土地理院数值地図 $5 \mathrm{~m} メ ッ シ ュ$ 標 高と国土交通省国土数值情報の「河川を使用する.

本研究では, 外水汇濫・内水汇濫の浸水履歴を基に, それぞれの浸水域からの距離・標高差を用いて，「浸水 域の夕「浸水域から直線距離 $100 \mathrm{~m}$ 以内で, かつ, 最寄 りの浸水域の平均標高との標高差が+1 $1 \mathrm{~m}$ 以内，あるいは， $+3 \mathrm{~m}$ 以内」を水害危険地域としたダミー指標を設定して 分析する. なお，内水汇濫・外水汇濫それぞれに対する 3 種類の水害危険地域設定は，「浸水域「浸水域+標高 $1 \mathrm{~m}\rfloor$ 浸水域+標高 $3 \mathrm{~m}\rfloor$ と以後標記する.

\section{(3) 分析}

対象期間の2001年以降は，以前のバブル崩壊後の地価 下落が継続した期間に比べれば，地価変動は沈静化して いる. しかし，2007年末のサブプライムローン問題の顕 在化や2008年9月のリーマン・ショックにより地価が上 昇から下落に転じたように，地価形成構造に大きな変化 が生じており，この期間の地価分析の支障となる.

本研究は, 水害危険地域内外の取引地価の差に, 時期 による変化が生じたかを分析することを目指しており， 水害危険度指標以外の土地属性が各期の地価に与えた影 響を取り除きたい，そこで，水害危険度指標以外の土地 属性に関して各期のパラメータを推定し，それぞれの取 引に関して水害危険度がないと仮定した場合の地価を算 定した上で, 取引地価との比較を通して, 水害危険度指 標が取引地価へ与えた影響の大きさを分析する.

a) 水害危険度以外の土地属性のパラメータ推定

水害危険度指標以外の土地属性に対するパラメータは,

\section{表-1＼cjkstart取引地価と地価公示価格の記述統計量}

\begin{tabular}{|c|c|c|}
\hline 統計量 & 取引地価 & 地価公示価格 \\
\hline \hline 件数 $($ 件 $)$ & 1953 & 144 \\
\hline 平均值 $\left(\right.$ 円 $\left./ \mathrm{m}^{2}\right)$ & 441,423 & 450,938 \\
\hline 中央值 $\left(円 / \mathrm{m}^{2}\right)$ & 442,980 & 441,500 \\
最小值 $\left(円 / \mathrm{m}^{2}\right)$ & 20,692 & 315,000 \\
\hline 最大值 $\left(\right.$ 円 $\left./ \mathrm{m}^{2}\right)$ & $1,437,438$ & 775,000 \\
\hline 標準偏差 $\left(\right.$ 前 $\left./ \mathrm{m}^{2}\right)$ & 138,803 & 71,022 \\
\hline
\end{tabular}

2001年から2013年までの取引事例に対応した，2002年か ら2014年までの地価公示を用いて推定する.

説明変数として「地積」「指定容積率」「最寄り駅から主 要駅までの鉄道所要時間」「最寄り駅までの距離」を用い た. 各説明変数・被説明変数について対数值を用いるか をOLSで確認し, 決定係数が最大となる「単位面積当た り地価の対数值」を，「地積の対数值」指定容積率」「鉄道 所要時間の対数值」「最寄り駅までの距離の対数值」で説 明する地価関数を設定した. 推定結果を表-2に示す.

b) 水害危険度の取引地価に対する影響変化の抽出

水害危険度以外の土地属性に対するパラメータ推定結 果を用いて, 各取引事例に対応する水害危険度が無い状 態の地価（以後，無危険度地価と記す）を算定した. 次 に, 取引地価を被説明変数, 無危険度地価と水害危険地 域ダミーを説明変数とし，「水害危険地域ダミーのパラ メータ変化時点」水害危険地域ダミーの変化時点前のパ ラメータ」「水害危険地域ダミーの変化時点のパラメータ 変化量」を推定した.

変化時点推定モデルは, 地点 $i$, 時間 $t$ の単位面積当 たりの取引地価 $\left(円 / \mathrm{m}^{2}\right)$ を $P_{i t}$, 無危険度地価を $P^{\prime}{ }^{\prime}$, 水 害危険地域ダミーを $D_{i}$, 変化時点 $\theta$ の後であることを 表すダミ一变数を $I(\theta)$, 無危険度地価に対するパラメー 夕を $\beta 0$, 水害危険度ダミーに対する変化時点前のパラ メータを $\beta_{B}$, 変化時点の変化量を表すパラメータを $\beta_{C}$, 攪乱項 Eit の分散を $\sigma^{2}$ とすると, 式(3)で表される.

$\ln P_{i t}=\ln P_{i t}{ }^{\prime} \beta_{0}+D_{i} \beta_{B}+D_{i} I_{t}(\theta) \beta_{C}+\varepsilon_{i t}, \varepsilon_{i t} \sim N\left(0, \sigma^{2}\right)$

Spirling $(2007)^{14)}$ の変化時点推定法は, 時点は離散的で あることを前提とする. そこで, 取引日を基準に半年単 位に6月末・12月末で取引地価を区切り分析寸る.

MCMCによる式(3)のパラメータ推定は，ギブス・サ ンプラーを用いて 15,000 回繰り返し，そのうち最初の 5,000回の結果をburn-in periodとして破棄した. 残りの 10,000回のシミュレーションで得られた, 離散的な変化 時点の最頻值と標準偏差, および，その他のパラメータ の平均值と標準偏差を表-3に示す. なお, 変化時点が推 定された場合は, 参考として, 変化時点後の水害危険地 域ダミーの取引地価への影響を表す $\beta_{B}+\beta_{C}$ を記載する.

まず，外水汇濫浸水履歴に基づく水害危険地域設定に よる分析では，いずれの設定に関しても変化時点につい て統計的に有意な結果は得られなかった. また, 推定さ れた水害危険地域ダミーに対する全期間共通のパラメー 夕は，「浸水域」では有意な正の值となったが，「浸水域十 標高 $1 \mathrm{~m} / 3 \mathrm{~m}$ 」では有意な結果が得られなかった。

次に, 内水汇濫浸水履歴に基づく水害危険地域設定に よる分析では，「浸水域」を危険地域とした推定では変化 時点は得られず，水害危険地域ダミーに対する全期間共 通のパラメータも統計的に有意ではなかった.

しかし, 内水汇濫の「浸水域+標高 $1 \mathrm{~m} / 3 \mathrm{~m} 」$ を危険地域 とした設定では, 水害危険地域ダミーに対するパラメー 
表-2 公示地価を用いた水害危険度以外のパラメータ推定結果

\begin{tabular}{|c|c|c|c|c|c|c|c|c|c|c|}
\hline 年 & \multicolumn{2}{|c|}{ 切片 } & \multicolumn{2}{|c|}{ (対数)地積 } & \multicolumn{2}{|c|}{ 指定容積率 } & \multicolumn{2}{|c|}{ (対数) 鉄道所要時間 } & \multicolumn{2}{|c|}{ (対数) 最寄り駅距離 } \\
\hline 2002 & 13.1 & $* * *$ & 0.0967 & $* * *$ & 0.000661 & $* * *$ & -0.108 & $* * *$ & -0.0508 & $* * *$ \\
\hline 2003 & 13.1 & $* * *$ & 0.0875 & $* * *$ & 0.000655 & $* * *$ & -0.114 & $* * *$ & -0.0534 & $* * *$ \\
\hline 2004 & 13.2 & $* * *$ & 0.0909 & $* * *$ & 0.000623 & $* * *$ & -0.125 & $* * *$ & -0.0592 & $* * *$ \\
\hline 2005 & 13.2 & $* * *$ & 0.0929 & $* * *$ & 0.000600 & $* * *$ & -0.124 & $* * *$ & -0.0603 & $* * *$ \\
\hline 2006 & 13.1 & $* * *$ & 0.0961 & $* * *$ & 0.000582 & $* * *$ & -0.120 & $* * *$ & -0.0615 & $* * *$ \\
\hline 2007 & 13.1 & $* * *$ & 0.0931 & $* * *$ & 0.000549 & $* * *$ & -0.113 & $* * *$ & -0.0593 & $* * *$ \\
\hline 2008 & 13.1 & $* * *$ & 0.114 & $* * *$ & 0.000505 & $* *$ & -0.109 & $* * *$ & -0.0600 & $* * *$ \\
\hline 2009 & 13.2 & $* * *$ & 0.137 & $* * *$ & 0.000481 & * & -0.121 & $* * *$ & -0.0630 & $* * *$ \\
\hline 2010 & 13.3 & $* * *$ & 0.126 & $* * *$ & 0.000437 & $*$ & -0.139 & $* *$ & -0.0750 & $* *$ \\
\hline 2011 & 13.1 & $* * *$ & 0.126 & $* * *$ & 0.000441 & & -0.119 & $* * *$ & -0.0686 & $* *$ \\
\hline 2012 & 13.3 & $* * *$ & 0.103 & $* * *$ & 0.000309 & & -0.139 & $* * *$ & -0.0740 & $* *$ \\
\hline 2013 & 13.4 & $* * *$ & 0.0840 & $* * *$ & 0.000252 & & -0.144 & $* * *$ & -0.0744 & $* * *$ \\
\hline 2014 & 13.4 & $* * *$ & 0.0980 & $* * *$ & 0.000260 & & -0.146 & $* *$ & -0.0826 & $* *$ \\
\hline
\end{tabular}

ただし，*: $5 \%$ 有意 **: $1 \%$ 有意 $* * *: 0.1 \%$ 有意

表-3 水害危険地域ダミーの影響の変化時点・パラメータ推定結果

\begin{tabular}{|c|c|c|c|c|c|c|c|c|}
\hline \multirow{2}{*}{\multicolumn{2}{|c|}{ 水害危険地域設定 }} & \multirow{3}{*}{$\frac{\text { 変化時点 } \theta}{\text { なし }}$} & \multirow{3}{*}{$\begin{array}{c}\text { 無危険度地価 } \beta_{0} \\
0.999(0.000220)^{* * *}\end{array}$} & \multicolumn{5}{|c|}{ 水害危険地域ダミー } \\
\hline & & & & \multicolumn{2}{|c|}{ 変化前 $\beta_{B}$} & \multicolumn{2}{|c|}{ 変化量 $\beta_{C}$} & \multirow{2}{*}{$\frac{\text { 変化後 } \beta_{B}+\beta_{C}}{-}$} \\
\hline \multirow{3}{*}{$\begin{array}{l}\text { 外 } \\
\text { 水 }\end{array}$} & 浸水域 & & & 0.0701 & $(0.0289) * *$ & & - & \\
\hline & 浸水域+標高 $1 \mathrm{~m}$ & なし & $0.999(0.000220)^{* * *}$ & 0.00654 & $(0.0175)$ & & - & - \\
\hline & 浸水域+標高 $3 \mathrm{~m}$ & なし & $0.999(0.000220)^{* * *}$ & -0.00559 & $(0.0185)$ & & - & - \\
\hline \multirow{3}{*}{$\begin{array}{l}\text { 内 } \\
\text { 水 }\end{array}$} & 浸水域 & なし & $0.999(0.000210)^{* * *}$ & 0.0621 & $(0.644)$ & & - & - \\
\hline & 浸水域+標高 $1 \mathrm{~m}$ & 2011年6月末 (0.28年) & $0.999(0.000220)^{* * *}$ & 0.0462 & $(0.0206) *$ & -0.188 & $(0.0380) * * *$ & -0.142 \\
\hline & 浸水域+標高 $3 \mathrm{~m}$ & 2011年6月末 (0.05年) & $0.999(0.000220)^{* * *}$ & 0.0369 & $(0.0174) *$ & -0.197 & $(0.0309) * * *$ & -0.16 \\
\hline
\end{tabular}

ただし，( )内は標準偏差，*: 5\%有意 **: 1\%有意 ***: 0.1\%有意,

タの変化時点として2011年6月末が得られた．変化時点 前のパラメータは正となったが，変化時点におけるパラ メータ変化量はそれぞれ-0.188，-0.197と推定された。 こ の水害危険地域ダミーのパラメータの変化量は，2011年 6月末を境に水害危険地域内で取引地価が約17から $18 \%$ 下落したことを意味する.

\section{(4) 考察}

まず，外水汇濫履歴に基づく水害危険地域設定に関す る分析について考察する.

いずれの水害危険地域設定に対しても，時間の経過に 対して取引地価一の影響の大きさに統計的に有意な変化 は生じていないとの結果が得られた. 分析対象地域では, 2005年9月に大規模な外水汇濫が生じたにも関わらず, この水害による影響は観察されていない.

「浸水域」を水害危険地域と設定した場合，水害危険地 域ダミーに対する全期間共通のパラメータは正となり， 外水汇濫履歴地域の取引地価が高いとの結果が得られて いる. 河川近傍の外水汇濫履歴地域では, 水辺に近いア メニティによる効果が水害危険性よりも高く不動産市場 で評価されている可能性が示唆され，水害やその他の防 災意識に影響を与える事象の発生に関わらず，この構造 が変化していないことが推察される。

また, 「浸水域+標高 $1 \mathrm{~m} / 3 \mathrm{~m} 」$ を水害危険地域とした場 合, 水害危険地域ダミーのパラメータは有意ではなく,
不動産市場で評価されていないとの結果が得られた.

以上より，対象地域では外水汇濫履歴は期間を通して 取引地価に影響を与えておらず，地域住民・社会の外水 汇濫危険性に対する認識は低い可能性が示唆される.

次に, 内水汇濫履歴を基に作成した水害危険地域ダ ミーに関する分析について確認する。

「浸水域」を水害危険地域とした場合，変化時点が得ら れず，また水害危険地域ダミーのパラメータも有意では ない. たびたび内水汇濫が発生しているにも関わらず, その履歴は取引地価に反映されていないことが分かる.

しかし,「浸水域+標高 $1 \mathrm{~m} / 3 \mathrm{~m} 」$ の水害危険地域設定で は，2011年6月末を境とした大幅な取引地価の下落が確 認された。これは，2011年3月に発生した東日本大震災 をきっかけに地域住民・社会の防災意識が高まり，特に これまで水害危険性を強く認識していなかった内水汇濫 履歴地域の周辺で認識が高まり, 取引地価に織り込まれ たと考えられる.

以上より, 内水汇濫履歷地域の周辺では，東日本大震 災後に取引地価下落が顕著であることから，地域住民・ 社会の防災意識が向上した可能性が示唆される.

\section{5. 結論}

本研究は, 神田川流域を対象に, 水害危険度指標が取 引地価に与える影響が変化する時点を分析し，地域住民 
や社会が有する水害危険性認識の変化の把握を試みた. 水害区域図に記録された汇濫履歴地域に基づく水害危 険地域設定を行い，取引地価を分析した結果，内水汇濫 履歴地域周辺では，東日本大震災を機とした取引地価の 下落が確認された。未曾有の被害をもたらした東日本大 震災の経験によって，地域住民・社会の防災意識が向上 し，これまで水害危険性が強く意識されていなかった地 域の取引地価に影響を与えた可能性が示唆される.

一方, 外水汇濫履歴地域とその周辺や，内水汇濫履歴 地域では，水害危険性が地価に与える影響は変化してい ないとの結果が得られた。これらの地域では地域住民・ 社会が以前から水害危険性を認識していたため，地価へ の影響が変化しなかったと解釈できる，ただし，水害危 険地域では地域外と比べ，取引地価が高いとされている これは，水辺への近接環境を高く評価するアメニティ効 果が，水害危険性の負の影響を卓越している可能性が考 えられる. アメニティ効果と水害危険性が地価に与える 影響を分離するためには，水害危険性が異なる河川流域 間の比較分析を行う必要がある.

なお，本分析手法を低発生頻度の大規模水害被災地域 に対して適用すると，より顕著な地価変化を抽出できる 可能性がある。しかし，被災後の地価動向を観察するに は，被災後も浸水域やその周辺で不動産需要があり，多 数の取引が成立する必要であるため, 分析対象地域は都 市域に限られる. 本分析手法を適用できる他の地域に関 する分析を通じて，地価変化や地域住民・社会の水害危 険性認識について地域間比較を今後検討したい.

本研究では，防災意識の向上が原因と考えられる地価 下落の発生は観察されたが，防災施設整備による水害危 険性の緩和に起因寸る地価上昇は検出できなかった，災 害発生など地価下落をもたらす事象は多くの人に知覚さ れや寸いため, 変化は急激に生じると考えられる，一方， 防災設備の供用開始など地価上昇をもたらす事象は，必 ずしも地域住民の多くが認識するとは限らず，水害危険 性の低下をすぐに体感することも難しい，そのため，地 価上昇は，たとえ生じたとしても緩やかな変化であると 予想されるため, 急激な変化の発生時点を分析する本研 究で用いた手法では検出できなかった可能性がある.

また，今回の分析から得られた東日本大震災をきっか けとした地価下落が，その後も継続しているかは疑わし い. 東日本大震災後, 東京湾岸の住宅が忌避され需要が 急減したが，五輪誘致の成功により以前よりも人気が高 まっていると言われている。 このように不動産市場にお ける評価の変化も一過性に留まる可能性もあり, 本研究 の分析対象地域においても水害危険性が取引地価に与え る影響の増加が継続しているかは不明である．地価の回 復過程は穏やかな変化だと考えられるため, 本研究で用 いた分析手法では発見できない可能性が高い. 今後, 水 害危険性が取引地価に与える影響の長期的な変動の分析 手法を検討寸る必要があると考えている.
謝辞 : 本研究は, (公財) 旭硝子財団平成26年度研究奨励 の助成を受けた (公財) 東京都不動産鑑定士協会との共同 研究成果である. 不動産取引価格事例は国土交通省土 地・建設産業局不動産市場整備課，水害区域図は同水管 理・国土保全局河川計画課より提供いただいた。また， 取引物件の住所から座標への変換は, 東京大学空間情報 科学研究センターが提供するCSVアドレスマッチング サービスを使用した．ここに記し，感謝の意を表す。

\section{参考文献}

1) 例えば, IPCC: Climate Change 2013: The Physical Science Basis. Contribution of Working Group I to the Fifth Assessment Report of the Intergovernmental Panel on Climate Change, Cambridge University Press, 2013.

2) 劉 暉: 地価データを用いた水害リスクプレミアムの推計に 関する方法論的研究, 京都大学修士論文, 2010 .

3) 寺本雅子, 西澤諒亮, 市川 温, 立川康人, 椎葉充晴: 地価分 析を用いた水災害リスクに対する住民意識の評価に関する 研究, 水工学論文集, Vol. 52, pp. 457-462, 2008.

4) 市川 温, 松下将士, 椎葉充晴: 水災害と地価の関係に関す る調査研究, 京都大学防災研究年報, Vol.45, B-2, 2002.

5) 篠村 進: 都市型水害におけるハザードマップ効果の考察, 政策研究大学院大学修士論文, 2010.

6) 例えば，金本良嗣: ヘドニック・アプローチによる便益評 価の理論的基礎，土木学会論文集, No.449, pp.47-56, 1992.

7) 斎藤良太: 首都圈における浸水危険性の地価等への影響, 季 刊住宅土地経済, 58,pp. 19-27, 2005.

8）岩橋 佑, 平松敏史, 塚井誠人, 奥村 誠: 地価 -土地利用モ デルを用いた水害リスクの影響分析, 土木計画研究・論文 集, Vol. 23, No. 2, pp. 291-297, 2006.

9) 岡川 梓, 日引 聡, 小嶋秀人: ヘドニック・アプローチによ る東京都区部の洪水被害額の計測—浸水リスクの内生性を 考慮した分析一，環境経済・政策研究, Vol. 5, pp. 58-71, 2011.

10) 瀬谷 創, 山形与志樹, 村上大輔, 堤 盛人: 水害リスクがマ ンション価格に与える影響に関するへドニック分析 : 内生 変数を考慮した空間計量経済モデルの適用, ジャレフ・ ジャーナル, No.6, pp.17-36, 2013.

11) 高木朗義, 大野英治, 森杉壽芳, 沢木真次: 治水事業の経済 効果計測に関する研究, 土木計画学研究・論文集, Vol. 11, pp. 191-198, 1993.

12) 森杉壽芳, 高木朗義, 小池淳司: 治水事業の便益計測手法一 不確実性下における便益計測手法の提案一, 土木計画学研 究・講演集, No. 17, pp. 299-302, 1995.

13) 玉井昌宏, 石原千嘉: ヘドニック・アプローチを用いた寝屋 川流域における治水安全性の経済評価, 環境システム研究, Vol. 27, pp. 435-440, 1999.

14) Spirling, A.: Bayesian approach for limited dependent variable change point problems, Political Analysis, Vol. 15, pp. 387-405, 2007.

(2015. 9. 30受付) 